\title{
The bud midge Prodiplosis longifila: Damage characteristics, potential distribution and presence on a new crop host in Colombia
}

\author{
Luis M Hernandez ${ }^{1,2}$, Yoan C Guzman ${ }^{1,2}$, Adriana Martínez-Arias ${ }^{3,4}$, Maria R Manzano ${ }^{1,2^{*}}$ and John J Selvaraj ${ }^{3,4}$
}

\begin{abstract}
The Dipteran Prodiplosis longifila is a severe pest, mainly of Solanaceae, in South America and some years ago it damaged Tahiti lime crops in the United States. It is a potential invasive pest. Despite its presence in Colombia, nothing is known regarding the taxonomic identification of $P$. longifila or the characteristics of the damage it produces. Moreover, the current and potential distributions of this pest are unknown. To determine these factors, $P$. longifila was sampled in several Solanaceae- and Citrus ${ }^{\times}$latifolia (Tahiti lime)-producing areas in Colombia. The larvae consumed tender foliage, flowers and fruits in tomato, fruits in sweet pepper, and buds in Tahiti lime. P. longifila was not found in asparagus or in potatoes. Its presence in Tahiti lime was previously unknown in Colombia. Adults recovered in the laboratory were taxonomically identified using male morphological characteristics such as the shapes of the genitalia, antenna and wing. P. longifila was found in the Andean region of Colombia. The ecological niche model for populations found in tomato suggests that $P$. longifila is limited in its distribution by altitude and variables associated with temperature and precipitation. The highest probability of occurrence is in areas where tomato, sweet pepper and the new host, Tahiti lime, are grown. Therefore, it is necessary to implement preventive measures, such as planting tomato materials free of $P$. longifila larvae, in areas where the pest is not yet present but where there is the potential for its development.
\end{abstract}

Keywords: Bud midge; Ecological niche; Plant damage; Citrus; Solanum; Capsicum

\section{Background}

The bud midge Prodiplosis longifila Gagné is one of the most important pests of Solanaceae and asparagus in the Neotropics. In tomato, it can cause up to $100 \%$ loss in Colombia and up to $60 \%$ loss in Ecuador (Valarezo et al. 2003). In Peru, it causes considerable losses in crops of asparagus (Asparagus officinalis L; Cedano and Cubas 2012) and potato (Solanum tuberosum L.), where an infestation reaches up to 16\% of buds (Kroschel et al. 2012). In the United States (Florida), it affected up to $25 \%$ of flower buds in Tahiti lime (Citrus ${ }^{\mathrm{x}}$ latifolia Tanaka ex Q. Jimenez) in 1984 (Peña et al. 1987). P. longifila has also

\footnotetext{
* Correspondence: mrmanzanom@unal.edu.co

1 Departamento de Ciencias Agrícolas, Facultad de Ciencias Agropecuarias, Universidad Nacional de Colombia sede Palmira, Palmira, Valle del Cauca, Colombia

${ }^{2}$ Department of Agricultural Sciences, School of Agricultural Sciences, National University of Colombia at Palmira, Palmira, Valle del Cauca, Colombia

Full list of author information is available at the end of the article
}

been reported in pepper (Capsicum frutescens L.), sweet pepper (Capsicum annuum L.) and other companion plants (Gagné 1994; Gagné and Jaschhof 2014).

The larvae of $P$. longifila scrape the epidermal tissues of plant structures using piercing-sucking mouthparts (Gagné 1994). After undergoing three larval stages, the larvae pupate in the ground (Peña et al. 1989). Because larvae are small $(<1.9 \mathrm{~mm}$, Peña et al. 1989) and the crepuscular habits of adults make them difficult to find in the field, it is unclear what type of damage $P$. longifila causes. Our first objective was to characterise the damage caused by $P$. longifila in host plants. In Colombia, $P$. longifila feeds on foliar buds, flowers and fruits in tomato, whereas in the United States, it consumes the ovaries, stamens and pistils of Tahiti lime flower buds, causing their abortion (Peña et al. 1989). Based on the phytochemical distance of these two host plants, our second objective was to determine whether $P$. longifila of tomato is a morphologically different species from 
that reported in Tahiti lime in the United States. Because Colombia produces 92,304 tons of limes annually, representing 20.1\% of all national (Ministerio de Agricultura y Desarrollo Rural 2006) and 0.09\% of world lemon and lime production (FAO 2012), and the market for Tahiti lime is expanding in Europe and the United States (Ministerio de Agricultura y Desarrollo Rural 2006; Aguilar-Niño et al. 2012), our third objective was to determine if $P$. longifila is also found in Tahiti lime in Colombia.

Regarding the distribution of $P$. longifila in Colombia, this species was initially reported as a pest in the Valle del Cauca and the coffee region (Mena 2012), but its spread has expanded with concern to other regions of the country. Its current distribution is unknown. Risk maps based on the prediction of the climate distribution of a species are a management tool that allows the definition of current and future management areas of the insect pest (Ellsbury et al. 1999). These maps can be constructed based on the relationship of the species with different environmental factors (bio-variables) within its habitat (Guisan and Thuiller 2005). These maps can serve as ecological niche models (Peterson 2003) that allow the modelling of the invasion potential of the species (Mata et al. 2010). Our final objective was to determine the current and potential spatial distribution of $P$. longifila in tomato crops in Colombia, the main vegetable crop in the country. Tomato crops are planted in approximately 8,383 ha ( $8 \%$ of which is grown in the Valle del Cauca) that produce approximately 259,104 $\mathrm{t}$ /year with an average yield of $38.2 \mathrm{t} /$ ha per cropping season (DANE 2012).

Prodiplosis longifila larvae consume leaf buds, flowers (ovaries and stamens) and small fruits of tomato plants, fruits of sweet pepper and flower buds and flowers of Tahiti lime. This is the first report of the insect consuming Tahiti lime (flower buds) in Colombia. P. longifila was found between 739 and 2168 m.a.s.l in The Andes of Colombia and it is limited in its distribution by altitude and variables associated with temperature and precipitation.

\section{Results}

\section{Presence of $P$. longifila in sampled crops}

During the study, 167 batches of crops of peppers, asparagus, Tahiti lime, potato, paprika and tomato were sampled in Colombia, and one batch of Tahiti lime was sampled in the United States. Of the 167 plots sampled in Colombia, 28\% were located in the Valle del Cauca, followed by Boyacá (16\%), Antioquia (15\%), Huila (13\%), Santander (9\%), Caldas (5\%), Cundinamarca (4\%), Cauca (3\%), Nariño (3\%), Quindío (2\%) and, finally, Risaralda (2\%). As for the presence/absence of Cecidomyiidae, it was found that in Colombia, 53\% of the crops visited presented at least one species. In the tomato crop, it was found that $65 \%$ of the sites visited had $P$. longifila infestation, while in sweet pepper and Tahiti lime, $P$. longifila was found in $31 \%$ and $75 \%$ of the crops visited, respectively. $P$. longifila was not found in crops of hot peppers, potatoes or asparagus. The morphological identification determined that the adult from tomato, paprika and Tahiti lime are morphologically similar and correspond to $P$. longifila.

\section{Geographical distribution and morphological description of $P$. longifila}

In total, 540 microscope slides were prepared; 485 corresponded to P.longifila, and the rest corresponded to other species of Cecidomyiidae. Table 1 and Figure 1 show the presence of $P$. longifila by department and sampled crops.

P. longifila males have a soft and thin body and the R5 vein is slightly curved beyond the wing apex. The antennae have 14 flagellomeres, each consisting of two nodes (Figure 2a). The male gonopods are oriented dorsoventrally (Figure $2 b$ ).

\section{Characterization of damage in crops of tomato, pepper, paprika and Tahiti lime Tomato (Solanum lycopersicum)}

The female lays its eggs in leaf buds and flowers and under the calyx. When the larvae hatch, they feed by sucking the juices from the epidermal tissues of leaf buds (Figure 3a), flowers (ovaries and stamens, Figure 3b) and small fruits (Figure 3c); because of this, the tissues become brown only after the larvae drop to the soil. For example, in flowers, the stamens become brown, and later, the flower falls. The symptoms produced by $P$. longifila in flowers are very similar to those caused by Botrytis cinerea Pers. ex Fr. The fruit necrotises around the petiole, forming a spot known as "caregato" (in Spanish) or scab, and the fruit loses its commercial value (Figure 3a).

\section{Sweet pepper (Capsicum annuum)}

The larvae of $P$. longifila damage fruits. The larvae are white, and the small fruits $(2 \mathrm{~cm}$ in length) that are affected changed from green to fuchsia colour and stop their growth (Figure 3d).

\section{Tahiti lime (Citrus ${ }^{x}$ latifolia)}

P. longifila larvae were found in this crop consuming epidermal tissue of the ovaries, pistils and stamens of flower buds and flowers. In the ovary, necrosis was present after the larvae leave and after the abscission of flowers and small fruits. This study reports for the first time the presence of $P$. longifila feeding on flower buds of the Tahiti lime in Colombia (Figure 3e). Adults of $P$. longifila in the USA are morphologically similar to those of Colombia and, to those of tomato and sweet pepper. 
Table 1 Composition of Cecidomyiidae species collected in 11 Colombian departments in crops of Citrus ${ }^{\times}$Iatifolia (CL), Solanum lycopersicum (SL), Capsicum frutescens (CF), Capsicum annuum (CA), Solanum tuberosum (ST) and Asparagus officinalis (AO)

\begin{tabular}{|c|c|c|c|c|}
\hline Crop & Organ & Department & \# Samplings & Species \\
\hline \multirow[t]{8}{*}{$\overline{\mathrm{CL}}$} & \multirow[t]{8}{*}{ Flower buds } & \multirow[t]{2}{*}{ Antioquia } & \multirow[t]{2}{*}{4} & Prodiplosis longifila \\
\hline & & & & Prodiplosis floricola \\
\hline & & Caldas & 1 & Prodiplosis longifila \\
\hline & & \multirow[t]{2}{*}{ Huila } & \multirow[t]{2}{*}{3} & Prodiplosis longifila \\
\hline & & & & Prodiplosis floricola \\
\hline & & Santander & 1 & Prodiplosis longifila \\
\hline & & \multirow[t]{2}{*}{ Valle del Cauca } & \multirow[t]{2}{*}{3} & Prodiplosis longifila \\
\hline & & & & Prodiplosis floricola \\
\hline \multirow[t]{10}{*}{$\mathrm{SL}$} & \multirow{10}{*}{$\begin{array}{l}\text { Leaves, } \\
\text { flowers } \\
\text { and fruits }\end{array}$} & Antioquia & 18 & Prodiplosis longifila \\
\hline & & Boyacá & 12 & Prodiplosis longifila \\
\hline & & Caldas & 8 & Prodiplosis longifila \\
\hline & & Cauca & 4 & Prodiplosis longifila \\
\hline & & Cundinamarca & 6 & Prodiplosisl ongifila \\
\hline & & Huila & 12 & Prodiplosis longifila \\
\hline & & Quindío & 4 & Prodiplosis longifila \\
\hline & & Risaralda & 4 & Prodiplosis longifila \\
\hline & & Santander & 13 & Prodiplosis longifila \\
\hline & & Valle del Cauca & 26 & Prodiplosis longifila \\
\hline $\mathrm{CF}$ & Fruits & Valle del Cauca & 10 & Cecidomyiidae sp1 \\
\hline \multirow[t]{7}{*}{ CA } & \multirow[t]{7}{*}{ Fruits } & Antioquia & 2 & - \\
\hline & & \multirow[t]{2}{*}{ Huila } & \multirow[t]{2}{*}{6} & Prodiplosis longifila \\
\hline & & & & Cecidomyiidae sp1 \\
\hline & & \multirow[t]{2}{*}{ Santander } & \multirow[t]{2}{*}{1} & Prodiplosis longifila \\
\hline & & & & Cecidomyiidae sp1 \\
\hline & & \multirow[t]{2}{*}{ Valle del Cauca } & \multirow[t]{2}{*}{7} & Prodiplosis longifila \\
\hline & & & & Cecidomyiidae sp1 \\
\hline \multirow[t]{3}{*}{ ST } & - & Antioquia & 1 & - \\
\hline & - & Boyacá & 15 & - \\
\hline & - & Nariño & 5 & - \\
\hline $\mathrm{AO}$ & - & Cauca & 1 & - \\
\hline
\end{tabular}

Actual and predicted geographical distribution of $P$. longifila in Colombia

The insect was found between 739 and 2168 m.a.s.l. Figure 1 shows the distribution map of $P$. longifila in Colombia in tomato, sweet pepper and Tahiti lime. Regarding the predictive model on tomato, when analysing the correlation matrix of variables (Table 2), it was observed that the mean annual temperature (BIO_1) presents correlation coefficients close to 1 with the maximum temperature of the warmest month (BIO_5), the minimum temperature of the coldest month (BIO_6), the mean temperature of the wettest trimester (BIO_8) and the mean temperature of the driest trimester (BIO_9). The values of the variance inflation are presented in Table 2 . The significant variables associated with the presence/ absence of $P$. longifila, in order of most to least important, were: altitude, bio_4 (temperature seasonality), bio_10 (mean temperature of the warmest trimester), bio_11 (mean temperature of the coldest trimester), bio_19 (precipitation of the coldest trimester), bio_16 (precipitation of the wettest trimester) and bio_15 (precipitation seasonality). Altitude was the variable that had the most relevance. The map of the predictive model of the potential distribution of P. longifila in Colombia is presented in Figure 4. The AUC value for the training data was 0.968 and the accuracy of the predictive map was good with respect to the current distribution (kappa $=0.5$ ).

Based on the distribution prediction map generated for $P$. longifila, an increase in the distribution of $P$. longifila to Nariño, Meta and Caquetá is predicted. The values with a higher probability of occurrence are in Huila, Tolima and Valle del Cauca, where tomato, Tahiti lime and sweet pepper are grown.

\section{Discussion}

P. longifila feeds on tomato (leaf buds, flowers and fruits) and sweet pepper (small fruits). Here, it is reported for the first time consuming Tahiti lime in Colombia (flower buds). P. longifila damage is easily detected in tomato and sweet pepper, but in flower buds of Tahiti lime, it may be confused with fungal infections that can occur after larval feeding (Peña and Duncan 1992) or the spores can be transmitted by Cecidomyiidae adults (Mongrain et al. 2000). To avoid confusion, it is recommended to open the bud to check for the presence of larvae (Kikkert et al. 2006).

The identification of this new Colombian host indicates on one hand that $P$. longifila is polyphagous and not monophagous, like many other Cecidomyiidae (Hall et al. 2012), and that it adapts to phytochemically unrelated hosts. This adaptation probably occurs by a process of ecological speciation favouring alleles (Lenormand 2012) that allow adaptation to new and abundant hosts (Bourguet et al. 2014). The Tahiti lime, for example, was introduced in the Valle del Cauca (the zone where P. longifila was initially detected) in 1941 (Orduz and Mateus 2012) and P. longifila probably adapted to this host after coming from tomato that was being cultivated in the region. The propensity of this species for polyphagia may permit the expansion to other crops and areas of Colombia, as indicated by our risk map. Gagné and Jaschhof (2014) reported this species in five families and eight species of host plants. It is unknown if $P$. longifila causes economic damage in Tahiti lime in Colombia as it did in the United States, where it caused losses of up to 25\% (Peña et al. 1987). Because Tahiti lime is exported from 


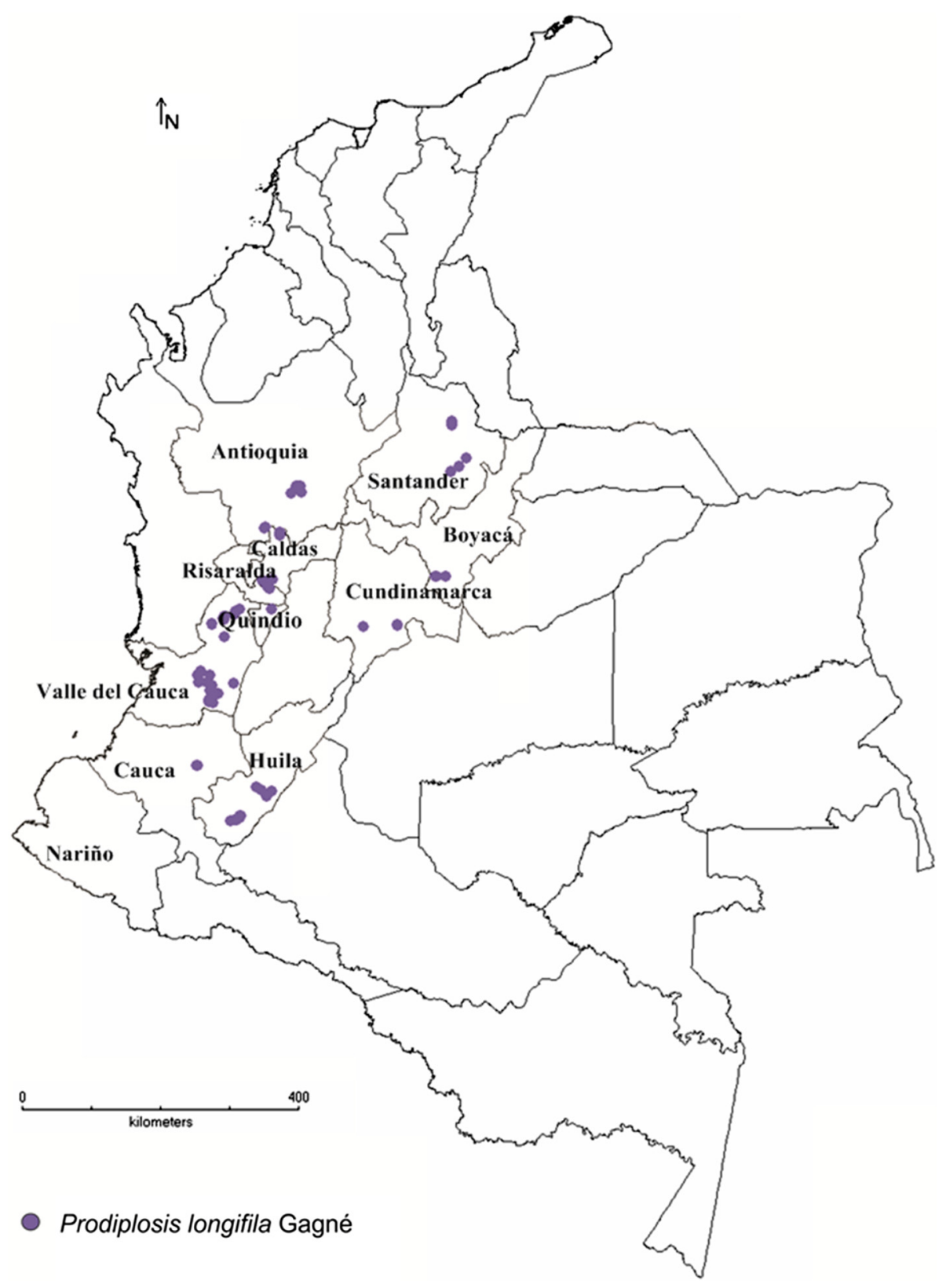

Figure 1 Map of the spatial distribution of Prodiplosis longifila in Colombia.

Colombia, the presence of $P$. longifila should be investigated further. On the other hand, the identification of $P$. longifila was carried out only by morphological characteristics and therefore DNA analysis is needed to understand if the populations of $P$. longifila collected from different host plants correspond to a complex of cryptic species rather than a single polyphagous species as suggested by Mathur et al. (2012) for the cecidomyiid Dasineura oxycocanna. Crops are usually introduced on purpose by humans and offer a new resource where a pest can evolve from pre-existing local herbivores by ecological speciation (Bourguet et al. 2014).
Although Kroschel et al. (2012) and Cisneros (1995) reported $P$. longifila as a key pest in asparagus, it was not found on this host, an absence that coincides with that reported for Colombia by Caicedo and Bellotti (2001).

In the Andean highland tropics (altitude $>1000$ m.a.s.l.), the altitude is inversely correlated with temperature. This could be the reason why the pest was not found in potatoes in Colombia, given that optimal production of that crop occurs between 2500 and 3000 m.a.s.l. in the Andes (Espinal et al. 2005), while in Peru, it is a pest on potatoes grown in low coastal areas (altitude $<500$ m.a.s.l.) (Kroschel 


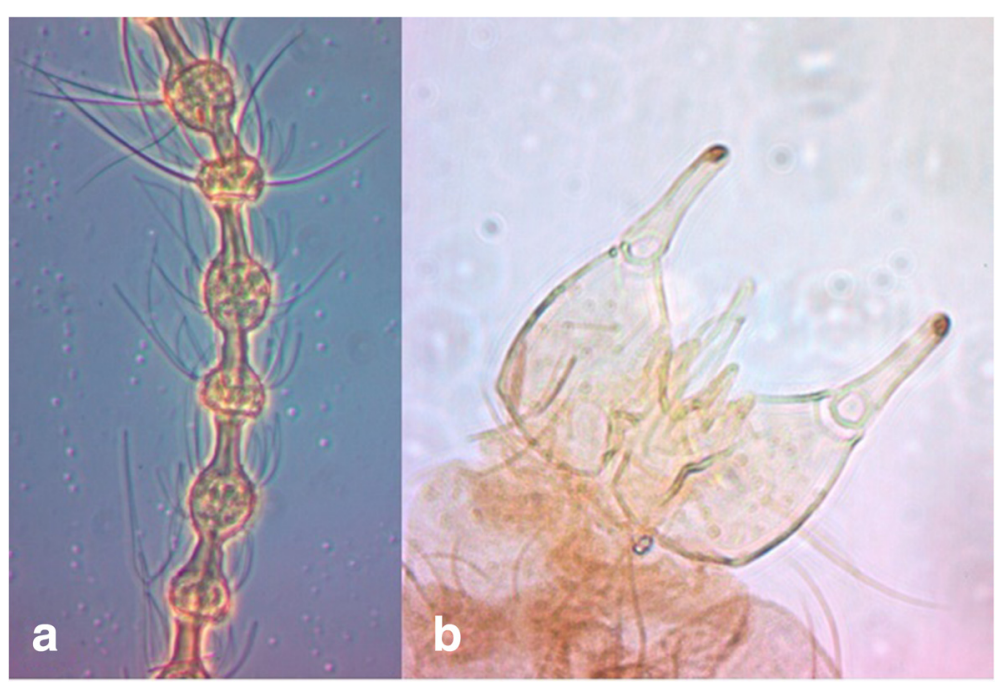

Figure 2 Prodiplosis longifila male (40X) a. antenna and $\mathbf{b}$. genitalia.

et al. 2012). Similarly, low temperatures should reduce the development time of $P$. longifila, as it happens with the predatory midge Feltiella acarisuga (Vallot) (Gillespie et al. 2000). In contrast, warm regions favour the presence of $P$. longifila (e.g.,Andean valleys at approximately 1000 metres), in part because increasing temperature decreases the development time in some species of Cecidomyiidae (Baxendale et al. 1984), favouring population growth (Olfert et al. 2006).

Variables associated with precipitation also influence the distribution of $P$. longifila. The infestation of $P$. longifila in tomato decreases in times of high rainfall (Mena 2012), possibly because larvae drop from the foliage to the ground and because the high concentration of moisture and lack of oxygen in the soil will cause the death of the pupae (Yee 2013). However, after a period of drought, the combination of accumulated temperature and precipitation will favour the end of the pupal stage on the ground, stimulating adult emergence (Jacquemin et al. 2014). It is unknown whether $P$. longifila presents larval diapause similarly to Contarinia nasturtii Kiefferas an adaptation to unfavourable conditions of temperature and humidity (Readshaw 1966; Chen and Shelton 2007).

The results suggest that $P$. longifila is adapted to the hot and temperate climates of the Andean region (well established in the Valle del Cauca and the Coffee Region: Caldas, Risaralda and Quindío), and even in the departments at risk, as in Meta and Caquetá, the species would be on the eastern slope of the Andes. Because the foothills of Meta have 1000 ha cultivated

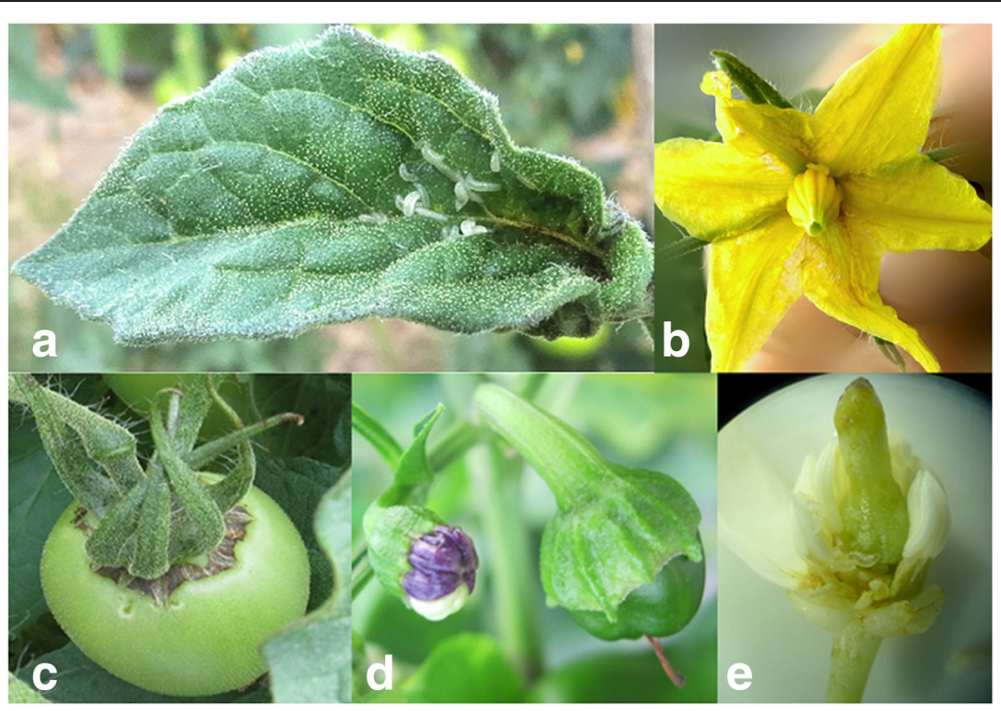

Figure 3 Prodiplosis longifila larvae damage in a. tomato leaf bud, $\mathbf{b}$. tomato flower, c. tomato fruit, d. sweet pepper fruit, and e. Tahiti lime floral bud. 
Table 2 Matrix of correlations between climatic variables*, values of variance inflation (VIF) and Student's $t$ test

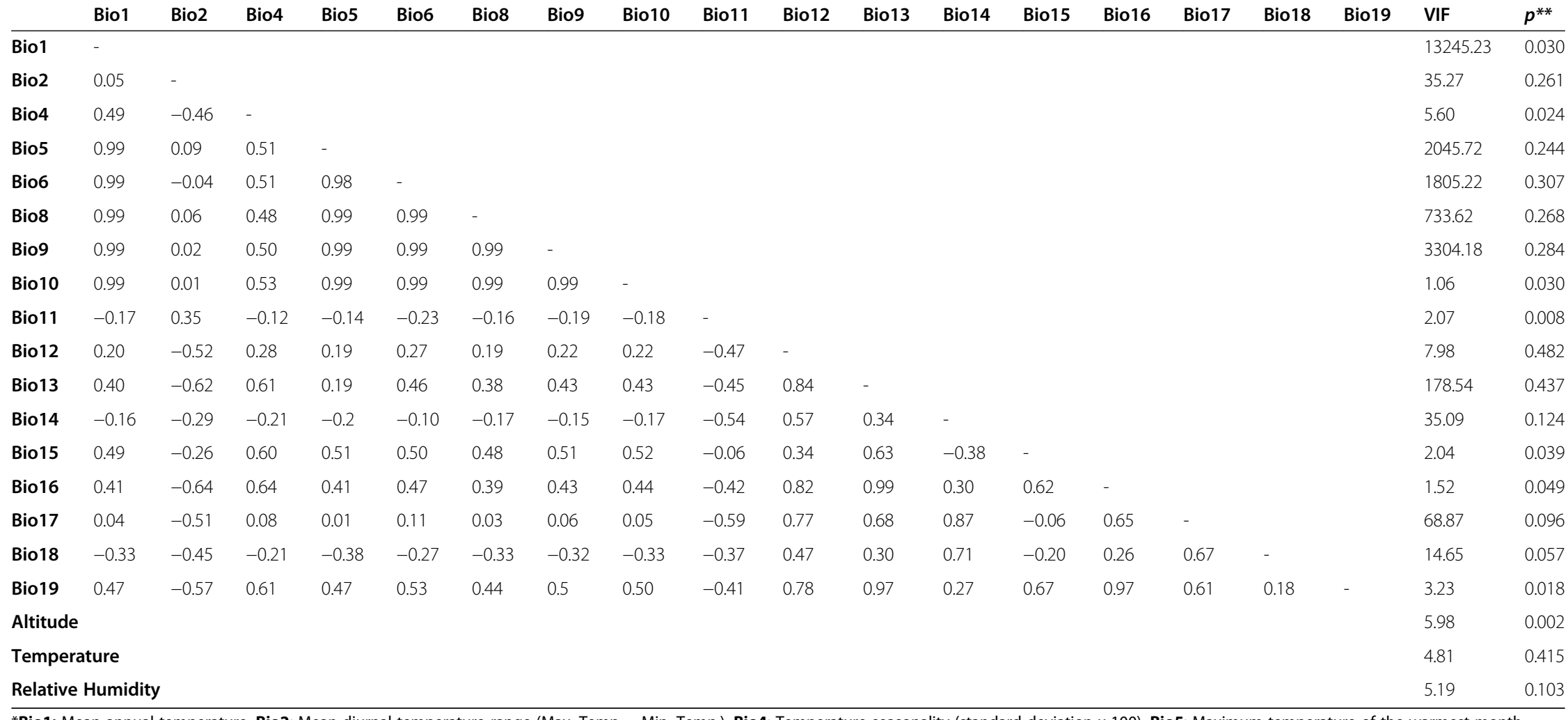

*Bio1: Mean annual temperature, Bio2: Mean diurnal temperature range (Max. Temp. - Min. Temp.), Bio4: Temperature seasonality (standard deviation x 100), Bio5: Maximum temperature of the warmest month, Bio6: Minimum temperature of the coldest month, Bio8: Mean temperature of the wettest trimester, Bio9: Mean temperature of the driest trimester, Bio10: Mean temperature of the hottest trimester, Bio11: Mean temperature of the coldest trimester, Bio12: Total annual precipitation, Bio13: Precipitation of the wettest month, Bio14: Precipitation of the driest month, Bio15: Precipitation seasonality (Coefficient of variation), Bio16: Precipitation of the wettest trimester, Bio17: Precipitation of the driest trimester, Bio18: Precipitation of the warmest trimester, Bio19: Precipitation the coldest trimester.

**Probability by Student's $t$ test. 


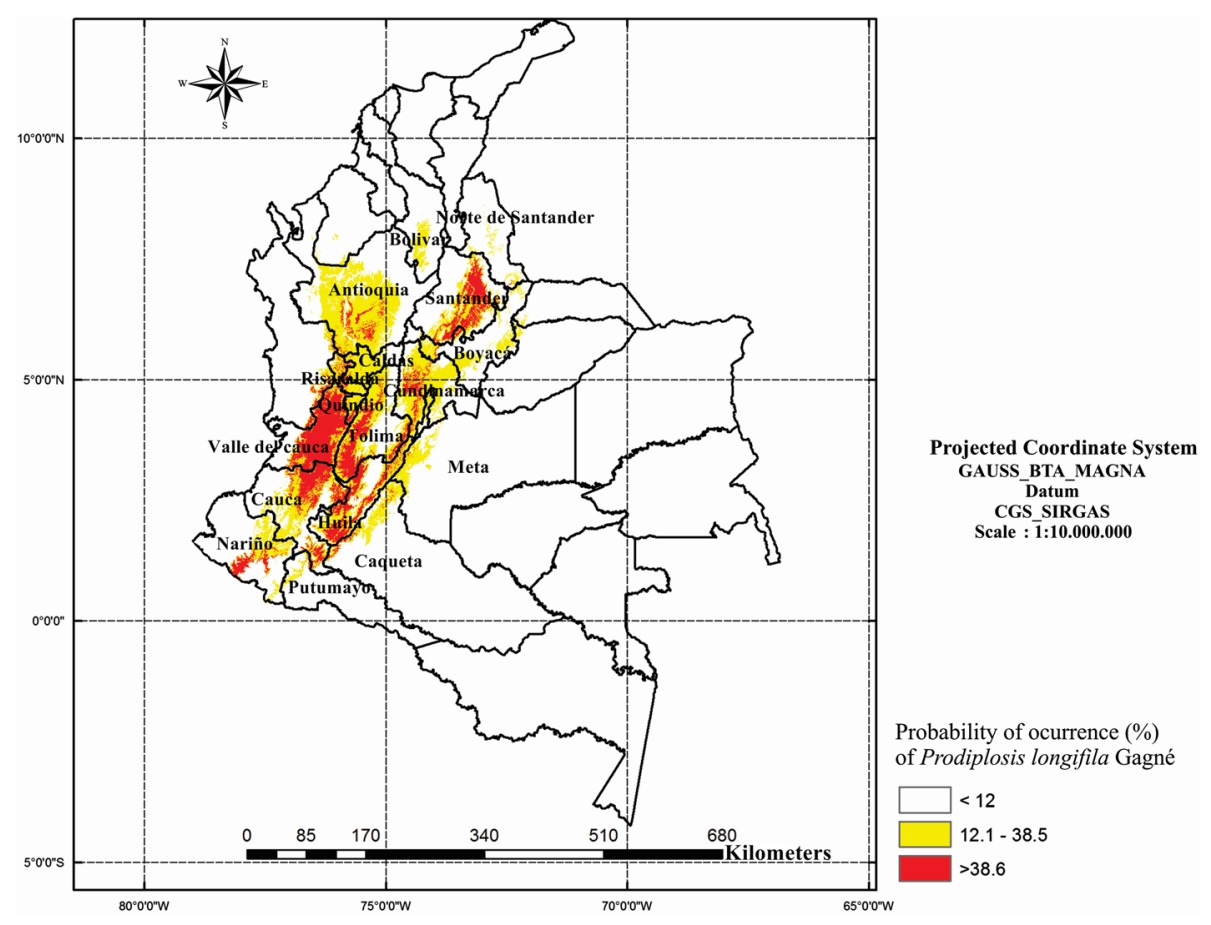

Figure 4 Predictive distribution map of Prodiplosis longifila in Colombia.

with Tahiti lime (10\% of the total Colombian citrus cultivation area) and are seen as an area to increase Tahiti lime production for exportation from Colombia (ClevesLeguízamo et al. 2012), it is necessary to define whether $P$. longifila causes economic damage to this crop even if molecular analysis reveal the presence of cryptic species.

Although the model reflects the great expansion of $P$. longifila on tomato in Colombia since it was first reported in the Valle del Cauca and the Coffee Region, the model also represents the climatic conditions that potentially limit the distribution of the species in the absence of negative interactions with other species in what constitutes its fundamental niche (Parsa et al. 2012). Therefore, the risk map does not take into account the anthropogenic effect related to the marketing of fruits and seedlings and the limited effectiveness of quarantine measures (Pysck and Richardson 2010) that control the transfer of plant material, which contributes to the distribution of the species (Worner and Gevrey 2006). Agricultural practices such as the frequent application of insecticides promote infestations of $P$. longifila (Kroschel et al. 2012). Additionally, tomato crop irrigation changes the soil moisture, which could interfere with the development of pupae (Chen et al. 2011). The model does not include the effect of natural enemies such as species of the parasitoid Synopeas (Hymenoptera: Platygasteridae), which is responsible for the partial regulation of $P$. longifila in Tahiti lime in the USA (Peña et al. 1990) and is present in asparagus infested with $P$. longifila (Cisneros
1995). P. longifila is parasitized by several species of Synopeas in Colombia (unpublished data by the authors), which could influence its distribution.

The predictions of our model call for an increase in preventive measures, such as monitoring the insect presence in nurseries from where $P$. longifila larvae could spread (Gagné 1986b; Sylven and Lövgren 1995). Unpublished data of the authors indicate that the development time of $P$. longifila in tomato and Tahiti lime fluctuates between 9 and 14 days, which would allow the relatively rapid establishment of the species in the areas of risk.

\section{Conclusions}

This study provides information on the biology of the gall midge Prodiplosis longifila, one of the most destructive pests of tomato and paprika in Colombia. P. longifila is reported for the first time attacking reproductive structures of Tahiti lime in Colombia. Microscopic preparations of $P$. longifila males are needed for taxonomic identification; the antennae have 14 flagellomeres with two nodes each, and the male gonopods are oriented dorsoventrally. The insect is distributed between Andean valleys located at 739 up to 2168 masl in The Andes of Colombia. Apparently, unchecked transport of plant material has contributed to the dispersion of the species, so sanitation measures should be implemented in nurseries. Pruning tomato leaves may reduce the population of $P$. longifila larvae. Besides altitude, the variables that most 
influence the distribution of $P$. longifila are temperature, relative humidity and precipitation. The infestation of $P$. longifila in tomato decreases during periods of high rainfall, possibly because larvae drop from the foliage to the ground, but also because the high concentration of moisture and lack of oxygen in the soil may increase pupal mortality. Prediction models based on tomato crop populations predict the distribution of the species on the foothills of Meta area, located on the eastern slope of the Andes, where 10\% of total Colombian citrus cultivation takes place. Some years ago $P$. longifila caused economic losses to Tahiti lime production in the USA, therefore it is important to further investigate its impact on Tahiti lime production in Colombia. However DNA analysis for $P$. longifila is required to understand if the populations of $P$. longifila collected from different host plants correspond to a complex of cryptic species rather than a single polyphagous species. These results will be fundamental to develop effective IPM strategies, including biological control programmes.

\section{Methods \\ Study site}

Between March 2012 and September 2013, crops of peppers, asparagus, Tahiti lime, potato, paprika and tomato were sampled in the departments of Antioquia, Boyacá, Caldas, Cauca, Cundinamarca, Huila, Nariño, Quindío, Risaralda, Santander and Valle del Cauca in Colombia in search of larvae of $P$. longifila. Leaf buds, flowers and fruits in early stages of development that showed signs of damage in tomato were inspected for larvae (Mena 2012); the leaves, flowers and fruits with symptoms of damage in pepper and paprika were also inspected. In asparagus, young buds were searched for larvae, while they were sought in the foliage, flowers and fruits of potatoes (Kroschel et al. 2012) and the flower buds of Tahiti limes (Peña et al. 1987). The discoloration and shape of the affected structures were described and photographed to characterize the damage.

\section{Taxonomic identification of $P$. longifila}

Plant structures that had damage and/or larvae were removed, packed in plastic containers $(20 \times 10 \mathrm{~cm})$ with wet paper towels to prevent drying and transported to the Laboratory of Entomology and Acarology of the National University of Colombia at Palmira. To obtain adults, recovery chambers were used, as described by Gagné (1994), and kept in an acclimated chamber (Panasonic MLR-351) under controlled conditions $\left(23^{\circ} \mathrm{C}\right.$, $75 \% \mathrm{HR}, 12 \mathrm{~L}: 12 \mathrm{O})$. Upon reaching full development, the adults were stored in 95\% ethyl alcohol.

Taxonomic identification was based on the morphology of males (Gagné 1986a; Gagné 1994); the abdomen, antennae and wings were removed from each individual, and the rest of the body was kept for further molecular identification. With the removed structures, microscope slides were made, according to the protocol of Gagné (1994). Adult $P$. longifila were collected in Tahiti lime of Florida (USA) and sent by JE Peña (University of Florida); these samples were also processed for identification.

\section{Distribution model of $P$. longifila}

To build the current distribution map of $P$. longifila, georeferenced points identified with a GPS (Garmin GPSMAP 60CSx) were mapped using the DIVA-GIS program.

The ecological niche model (Peterson 2003; Warren and Seifert 2011) was used to predict the distribution of P. longifila in tomato in Colombia. To build the model, 90 sampling points corresponding to tomato crops were used, and for its validation, 39 points were used. At each sampling point, the altitude was determined. Climatic data obtained from the WorldClim database (http:// www.worldclim.org, Hijmans et al. 2005) were used for the construction of the environmental layers of the ecological niche model. The database has 19 variables derived from temperature and precipitation.

Variables with more influence on the distribution of $P$. longifila were selected. This selection was done by using a multi co-linearity test to determine whether there was a correlation between the independent variables. This could inflate both the standard error and the confidence intervals and could prevent the determination of the significance of each variable on the dependent variable (Quinn and Keough 2002). Therefore, a Pearson correlation coefficient matrix was constructed with the 22 recorded variables (19 WorldClim variables plus 3 field variables). Variables with $R \geq 0.80$ were considered to be correlated (Lozier and Mills 2009). The tolerance value (1-r2) for each variable was then checked and expressed as a factor of overestimation of the variance (VIF $=(1$ r2) -1). A low tolerance indicates that the variable is correlated with one or more variables; therefore, VIF values above ten suggest a strong collinearity (Quinn and Keough 2002). Variables with VIF values $>10$ were eliminated. Finally, the association between the remaining variables and the dependent variable (the presence/ absence of $P$. longifila) was evaluated. To do this, a Pearson correlation was performed, and its significance was estimated by Student's $t$ test. Once the variables with the greatest effect on P. longifila were selected, MAXENT $3.3 .3 \mathrm{k}$ (Maximum Entropy, Elith et al. 2011) was used to construct the ecological niche model. This software generates an estimate of the probability of occurrence of the species as a function of the selected environmental variables (Phillips et al. 2006). The results from this program were processed in ArcGIS 9.3.

The Jackknife Maxent test was used to determine the importance of each variable and its relationship with $P$. 
longifila. To evaluate the model performance, the AUC (area under the curve) value, which is an independent measure of the threshold model performance, was used; AUC $=1.0$ optimum; AUC $=0.5$ weak (Araújo et al. 2005). The model was validated with Cohen's Kappa (Fielding and Bell 1997); if $0.4<$ Kappa $<0.75$, the model is considered good (Fielding and Bell 1997).

\section{Competing interests}

The authors declare that they have no competing interests.

\section{Authors' contributions}

MRM and JS conceived and designed the research. LMH, YCG and MRM conducted field surveys. LMH, YCG and MRM conducted laboratory activities. AM and JS developed the insect distribution model. All authors read and approved the manuscript.

\begin{abstract}
Authors' information
LMH: MSc, Departamento de Ciencias Agrícolas, Universidad Nacional de Colombia, sede Palmira, Carrera 32 12-00 Palmira, Colombia; YCG: MSc student Departamento de Ciencias Agrícolas, Universidad Nacional de Colombia, sede Palmira, Carrera 32 12-00 Palmira, Colombia; MRM: PhD, Associate Professor, Departamento de Ciencias Agrícolas, Universidad Nacional de Colombia, sede Palmira, Carrera 32 12-00 Palmira, Colombia; AMA: MSc student, Departamento de Ingeniería, Universidad Nacional de Colombia, sede Palmira, Carrera 32 12-00 Palmira, Colombia; JJS: PhD, Associate Professor, Departamento de Ingeniería, Universidad Nacional de Colombia, sede Palmira, Carrera 32 12-00 Palmira, Colombia
\end{abstract}

\section{Acknowledgements}

We thank Raymond Gagné (USDA, Washington) for his assistance in the identification of Cecidomyiidae, teaching Maria Manzano how to identify P. longifila in Washington, lending specimens for comparison, improving the manuscript and generous collaboration. Mrs. Sally Gagné is thanked for her kindness and nice time shared with Maria Manzano. J.E. Peña (IFAS, University of Florida, USA) is thanked for sending individuals of P. Iongifila and providing information to the research project. The following companies and researchers (Agronomist Engineer AE) are thanked for information and logistical support during the sampling: Agrícolas Unidas S.A. Támesis, Alexander Barrera (A.E. Basf Química Huila), Alvaro Caicedo (A.E. Corpoica, Palmira, Valle del Cauca), Carlos Barona (A.E. Basf Química, Santander), Cristian Martínez (A.E. Bayer), Edgar Ortegón (A.E. Syngenta, Cundinamarca), Edilberto Muñoz (.A.E. Hugo Restrepo and co. S.A.C.I, Valle del Cauca), Gustavo Cataño (A.E), Sonia Flor (Asoespárragos, Cauca), Wilinton Golondrino (Association of agricultural producers "El Progreso", Cauca) and Frutales Las Lajas (Valle del Cauca). We thank the farmers from different regions of Colombia for allowing us to sample their crops. This research was funded by Colciencias (1120-521-28402 Project) in collaboration with the Universidad Nacional de Colombia (HERMES 14974). We thank to Universidad Nacional de Colombia (HERMES 26124) and Jeffrey Stuart (University of Purdue) for improving the English and, two anonymous reviewers for their valuable comments.

\footnotetext{
Author details

${ }^{1}$ Departamento de Ciencias Agrícolas, Facultad de Ciencias Agropecuarias, Universidad Nacional de Colombia sede Palmira, Palmira, Valle del Cauca, Colombia. ${ }^{2}$ Department of Agricultural Sciences, School of Agricultural Sciences, National University of Colombia at Palmira, Palmira, Valle del Cauca, Colombia. ${ }^{3}$ Departamento de Ingeniería, Facultad de Ingeniería y Administración, Universidad Nacional de Colombia sede Palmira, Palmira, Valle del Cauca, Colombia. ${ }^{4}$ Department of Engineering, School of Engineering and Management, National University of Colombia at Palmira, Palmira, Valle del Cauca, Colombia.
}

Received: 18 December 2014 Accepted: 17 April 2015

Published online: 30 April 2015

\section{References}

Aguilar-Niño MJ, Escobar-Quijano MJ, Pássaro-Carvalho CP (2012) Situación actual de la cadena de cítricos en Colombia: limitantes y perspectivas In: Pássaro, C. (ed) Cítricos: cultivo, poscosecha e industrialización. Corporación Universitaria Lasallista, Caldas, pp. 7-47.

Araújo MB, Pearson RG, Thuiller W, Erhard M (2005) Validation of species-climate impact models under climate change. Glob Change Biol 11:1504-1513

Baxendale F, Teetes G, Sharpe P, Wu H (1984) Temperature-dependent model for development of nondiapausing sorghum midges (Diptera: Cecidomyiidae). Environ Entomol 13:1572-1576

Bourguet D, Ponsard S, Streiff R, Meusnier S, Audiot P, Li J, Wang ZY (2014) "Becoming a species by becoming a pest" or how two maize pests of the genus Ostrinia possibly evolved through parallel ecological speciation events. Mol Ecol 23:325-342

Caicedo AM, Bellotti AC (2001) Entomofauna asociada con el cultivo de espárrago en el departamento del Cauca, Colombia [Entomofauna associated with the cultivation of asparagus in the department of Cauca, Colombia]. Rev Colomb Entomol 35:15-21

Cedano CA, Cubas P (2012) Baeuveria bassiana (Bals) Vuill and Metarhizium anisioplae (Metsch.) Sorokin in the pupa control of Prodiplosis longifila Gagné on asparagus crop. Sci Agropecu 1:29-34

Chen M, Shelton A (2007) Impact of soil type, moisture, and depth on swede midge (Diptera: Cecidomyiidae) pupation and emergence. Environ Entomol 36:1349-1355

Chen M, Shelton A, Hallett R, Hoepting C, Kikkert J, Wang P (2011) Swede midge (Diptera: Cecidomyiidae), ten years of invasion of crucifer crops in North America. J Econ Entomol 104:709-716

Cisneros F (1995) Control de plagas agrícolas [Control of agricultural pests], 2dathth edn. AGCIS Electronics, Lima-Perú

Cleves-Leguízamo JA, Orduz-Rodríguez JO, Fonseca-Carreño JA (2012) Aportes de la investigación en cítricos al manejo agroecológico del cultivo en el piedemonte del departamento del Meta, Colombia. [Contributions of research in the agro citrus crop management in the foothills of the department of Meta, Colombia]. Rev. Inv Agra Ambi 3:85-96

DANE (2012) Encuesta Nacional Agropecuaria [National Agricultural Survey]. Available at: www.dane.gov.co. [Retrieved: September 20, 2012]

Elith J, Phillips S, Hastie T, Dudík M, Chee Y, Yates C (2011) A statistical explanation of MaxEnt for ecologists. Divers Distrib 17:43-57

Ellsbury M, Clay S, Fleischer S, Chandler L, Schneider S (1999) Use of GIS/GPS systems in IPM: Progress and reality. In: Kenedy G, Sutton T (eds) Emerging technologies for integrated pest management: Concepts, research, and implementation. APS PRESS, Minnesota, pp 419-438

Espinal CF, Martinez HJ, Pinzón N, Barrios CA (2005) La cadena de la papa en Colombia: Una Mirada global de su estructura y dinámica 1991-2005 [The potato chain in Colombia: A global look at its structure and dynamics 1991-2005]. Documento de Trabajo número 54. Ministerio de Agricultura y Desarrollo Rural. Observatorio Agrocadenas de Colombia. http://www.agronet.gov.co.

FAO (2012) Citrus fruit. Fresh and processed: Annual statistic. Available at: http://www.fao.org/fileadmin/templates/est/comm/Citrus/Documents/ Citrus_Bulletin_2012.pdf [Reviewed. October $5^{\text {th }}$, 2014]

Fielding A, Bell J (1997) A review of methods for the assessment of prediction errors in conservation presence/absence models. Environ Conserv 24:38-49

Gagné R (1986a) Revision of Prodiplosis (Diptera: Cecidomyiidae) with descriptions of three new species. Ann Entomol Soc Am 79:235-245

Gagné RJ (1986b) A new Nearctic species of Contarinia (Diptera: Cecidomyiidae) recently introduced into Hawaii on Cupressus (Cupressaceae). P Entomol Soc Wash 88:127-130

Gagné R (1994) The Gall Midges of the Neotropical Region. Cornell University Press, London, p 457

Gagné RJ, Jaschhof M (2014) A Catalog of the Cecidomyiidae (Diptera) of the world, 3rd edn, Digital version 2. USDA, Washington, USA

Gillespie D, Opit G, Roitberg B (2000) Effects of temperature and relative humidity on development, reproduction, and predation in Feltiella acarisuga (Vallot) (Diptera: Cecidomyiidae). Biol Control 17:132-138

Guisan A, Thuiller W (2005) Predicting species distribution: offering more than simple habitat models. Ecol Lett 8:993-1009

Hall D, Amarawardana L, Cross J, Francke W, Boddum T, Hillbur Y (2012) The chemical ecology of Cecidomyiid midges (Diptera: Cecidomyiidae). J Chem Ecol 38:2-22

Hijmans R, Cameron S, Parra J, Jones P, Jarvis A (2005) Very high resolution interpolated global terrestrial climate surfaces. Int J Climatol 25:1965-1978 
Jacquemin G, Chavalle S, De Proft M (2014) Forecasting the emergence of the adult orange wheat blossom midge, Sitodiplosis mosellana (Géhin) (Diptera: Cecidomyiidae) in Belgium. Crop Prot 58:6-13

Kikkert J, Hoepting C, Wu Q, Wang P, Baur R, Shelton A (2006) Detection of Contarinia nasturtii (Diptera: Cecidomyiidae) in New York, a new pest of cruciferous plants in the United States. J Econ Entomol 99:1310-1315

Kroschel J, Mujica N, Alcazar J, Canedo V, Zegarra O (2012) Developing integrated pest management for potato: experiences and lessons from two distinct potato production systems of Peru. In: He Z, Larkin R, W Honeycutt (eds) Sustainable potato production: global case studies, Springer, pp. 419-450

Lenormand T (2012) From local adaptation to speciation: specialization and reinforcement. International Journal of Ecology. doi:10.1155/2012/508458

Lozier JD, Mills NJ (2009) Ecological niche models and coalescent analysis of gene flow support recent allopatric isolation of parasitoid wasp populations in the Mediterranean. PLoS One 4(6), e5901

Mata R, Tidon R, Côrtes L, Júnior M, Diniz J (2010) Invasive and flexible: niche shift in the drosophilid Zaprionus indianus (Insecta, Diptera). Biol Invasions 12:1231-1241

Mathur S, Cook MA, Sinclair BJ, Fitzpatrick SM (2012) DNA Barcodes suggest cryptic speciation in Dasineura oxycoccana (Diptera: Cecidomyiidae) on cranberry, Vaccinium macrocarpon, and blueberry. $V$ corymbosum Fla Entomol 95(2):387-394

Mena Y (2012) Evaluación de la resistencia a Prodiplosis longifila Gagné (Diptera: (ecidomyiidae) en materiales segregantes de tomate cultivado y accesiones silvestres de Solanum habrochaites Knapp y Spooneer var. glabratum Evaluation of the resistance to Prodiplosis longifila Gagné (Diptera: (ecidomyiidae) in segregating materials of cultivated tomato and wild accessions of Solanum habrochaites Knapp and Spooneer var. glabratum. Tesis Maestría en Ciencias Agrarias. Universidad Nacional de Colombia, Facultad de Ciencias Agropecuarias, Palmira

Ministerio de Agricultura y Desarrollo Rural (2006) Sistema de inteligencia de mercados [Market intelligence system]. http://www.cadenahortofruticola.org/ admin/bibli/158inteligencia_de_mercados_lima_tahiti_fresca_marzo_2006.pdf [Retrieved: October 19, 2012]

Mongrain D, Couture L, Comeau A (2000) Natural occurrence of Fusarium graminearum on adult wheat midge and transmission to wheat spikes. Cereal Res Commun 28:173-180

Olfert O, Hallett R, Weiss RM, Soroka J, Goodfellow S (2006) Potential distribution and relative abundance of swede midge, Contarinia nasturtii, an invasive pest in Canada. Entomol Exp Appl 120:221-228

Orduz J, Mateus D (2012) Generalidades de los cítricos y recomendaciones agronómicas para su cultivo en Colombia [Overview of citrus and agronomic recommendations for its cultivation in Colombia]. In: Garcés LF (ed) Cítricos: cultivo, poscosecha e industrialización. Corporación Universitaria Lasallista, Caldas, pp 49-88

Parsa S, Kondo T, Winotai A (2012) The cassava mealybug (Phenacoccus manihoti) in Asia: First records, potential distribution, and an identification key. PLoS One 7:1-11

Peña JE, Duncan R (1992) Sampling methods for Prodiplosis/ongifila (Diptera: Cecidomyiidae) in Limes. Environ Entomol 21:996-1001

Peña JE, Baranowski RM, McMillan J (1987) Prodiplosis longifila (Diptera: (ecidomyiidae), a new pest of citrus in Florida. Fla Entomol 70:527-529

Peña J, Gagné R, Duncan R (1989) Biology and characterization of Prodiplosis longifila (Diptera: Cecidomyiidae) on lime in Florida. Fla Entomol 72:444-450

Peña J, Duncan R, Torres V (1990) Control of the citrus midge Prodiplosis longifila Gagné in southern Florida limes. P Interam Soc Trop Hortic 34:159-161

Peterson A (2003) Predicting the geography of species' invasions via ecological niche modeling. Quart Rev Biol 78:419-433

Phillips S, Anderson R, Schapire R (2006) Maximum entropy modeling of species geographic distributions. Ecol Model 190:231-259

Pysck P, Richardson DM (2010) Invasive species, environmental change and management, and health. Annu Rev Env Resour 35:25-55

Quinn G, Keough M (2002) Experimental design and data analysis for biologists. Cambridge University Press, United Kingdom, pp 127-130

Readshaw J (1966) The ecology of the swede midge, Contarinia nasturtii (Kieffer) (Diptera: Cecidomyiidae). I._Life-history and influence of temperature and moisture on development. B Entomol Res 56:685-700

Sylven E, Lövgren L (1995) Dasineura ingeris sp. n. (Diptera: Cecidomyiidae) on Salix viminalis in Sweden, including comparisons with some other Dasineura species on Salix. Syst Entomol 20:59-71
Valarezo O, Cañarte E, Arias M, Proaño J, Navarrete B, Garzón A, Jines A, Cuadros A, Porro M, Linzán L, Chávez J (2003) Diagnóstico, bioecología y manejo sostenible de la negrita Prodiplosis longifila en el Ecuador. Informe Final [Diagnosis, bio-ecology and sustainable management of the midge Prodiplosis longifila in Ecuador. Final Report]. Ecuador, Instituto Nacional Autónomo de Investigaciones Agropecuarias INIAP (Portoviejo)

Warren DI, Seifert SN (2011) Ecological niche modeling in Maxent: the importance of model complexity and the performance of model selection criteria. Ecol Appl 21:335-342

Worner S, Gevrey M (2006) Modelling global insect pest species assemblages to determine risk of invasion. J Appl Ecol 43:858-867

Yee WL (2013) Soil moisture and relative humidity effects during post diapause on the emergence of western cherry fruit fly (Diptera: Tephritidae). Can Entomol 145:1-10

\section{Submit your manuscript to a SpringerOpen ${ }^{\odot}$ journal and benefit from:}

- Convenient online submission

- Rigorous peer review

- Immediate publication on acceptance

- Open access: articles freely available online

- High visibility within the field

- Retaining the copyright to your article

Submit your next manuscript at $>$ springeropen.com 